\title{
Растительный покров малой реки Верхнего Поволжья (Ярославская область) в условиях естественного и измененного гидрорежима
}

Казанова Н.К.

Магистр биологии

Ярославский государственный университет им.П.Г.Демидова

Борисова М.А.

Кандидат биологических наук, доцент кафедры ботаники и микробиологии

Ярославский государственный университет им. П.Г. Демидова

Адрес:Ярославская область, город Ярославль, 150003, Советская, 14.

\section{Vegetation cover of a small river of the Upper Volga region (Yaroslavl region) in conditions of natural and altered hydro mode}

\author{
Kazanova N.K. \\ Master of Biology \\ Yaroslavl State University named after P.G. Demidov \\ Borisova M.A. \\ Microbiology \\ Yaroslavl State University named after P.G. Demidov
}

Candidate of Biological Sciences, Associate Professor of the Department of Botany and

Address: Yaroslavl region, city of Yaroslavl, 150003, Sovetskaya, 14.

\section{Аннотаиия.}

По результатам полевых обследований берегов и акватории реки Улеймы в нижнем, среднем и верхнем течении установлена общая картина зарастания речного русла по доминирующим видам с учетом основных групп экотипов. Выявлены закономерности пространственного размещения водных и прибрежно-водных фитоценозов с особенностями гидрорежима в различных ее участках и в связи с типами местообитаний. Показано соотношение группировок в целом и по отдельным участкам, их роль в зарастании речной экосистемы.

Ключевые слова: типы местообитаний, высшая водная растительность, пространственное распределение растительных сообществ, флористико-ценотическое разнообразие, природо-аквальный комплекс.

\section{Abstract}

Based on the results of field surveys of the coasts and water areas of the Uleima River in the lower, middle, and upper flow, the general picture of overgrowing of the riverbed by dominant species is set taking into account the main groups of ecotypes. The regularities of the spatial distribution of aquatic and coastal aquatic phytocenoses with the features of hydro regime in its various sections and in connection with the types of habitats are revealed. The correlation of the groups as a whole and for individual sites, their role in the overgrowth of the river ecosystem is shown.

Keywords: habitat types, higher aquatic vegetation, spatial distribution of plant communities, floristic-coenotic diversity, natural-aquatic complex.

Интерес ботаников России к экосистемам малых водотоков (ручьи, малые реки) определился в последние десятилетия в связи с осмыслением их первостепенной значимости, как для природы, так и для хозяйственных нужд человека. Малые реки являются начальным звеном гидрологической сети, формирующим более крупные реки, носителями гидрохимических особенностей ландшафтных водосборов различных природных зон, - это лицо ландшафтов, типов местностей. 
Малые реки отличаются от крупных водотоков не только размером, но и глубиной вреза. У них он, как правило, меньше, поэтому малая река вскрывает и дренирует меньшее число подземных водоносных горизонтов. Это предопределяет, во-первых, меньшую в целом водность малых рек, а, следовательно, и повышенную реакцию на циклические колебания климата. Во-вторых, малая река чутко реагирует на все антропогенные воздействия, которые осуществляются через поверхностный сток: прямые (водозабор, сброс) и косвенные (динамические процессы на водосборной площади, как: сведение леса в бассейне реки, распашка склонов, водная и сухая мелиорация и т.д.). Природные ресурсы рек очень велики, но в настоящее время они особо нуждаются в бережном отношении к ним, постоянном внимании и заботе со стороны человека, поскольку экологические системы малых рек являются наиболее хрупкими и уязвимыми.

Гидрофильная растительность является важнейшим звеном экосистемы водного объекта. Её видовое и ценотическое разнообразие определяется экологической неоднородностью водотока в целом и его отдельных участков, то есть степенью его экотопической расчлененности (линейная - чередование плесов и перекатов; поперечная - медиаль, рипаль, стрежень; вертикальная поверхностные и придонные участки).[10]

В этой связи целью данной работы было выявление связи видового и ценотического разнообразия, пространственного распределения и частоты встречаемости гидрофильной растительности с экотопами водотока на примере малой реки Улеймы.

Река Улейма; относится к малому водотоку (протяженность 83 км), вытекает из болота в малонаселённой местности [6]. В речной системе река Улейма является притоком реки Юхоть, которая впадает в реку Волга (Рыбинское водохранилище). В верховьях река протекает по отрогам Угличской возвышенности. На этом отрезке течение реки быстрое, встречаются перекаты, ширина не превышает 5 метров. В пригороде города Углич ширина русла увеличивается до 15-20 метров, скорость течения уменьшается. В верхнем и среднем течении река характеризуются естественным гидрорежимом, в низовье испытывает подпор от р. Юхоть, и сброса воды с Рыбинского и Угличского водохранилищ, действие которых просматривается вверх по течению до д. Кузнецово (около 6 км). В полноводные годы зона подпора может простираться выше до с. Покровское [8].

Русло реки сильно меандрирует до зоны подпора. Берега в основном крутые, подмытые и обрывистые, невысокие (1,5-3,0 м). По низким берегам распространены Alnus incana и виды гигрофильных ив (Salix caprea, S. fragilis, S. phylicifolia, S. triandra). Ниже по течению в зоне подпора высота берегов увеличивается до 10 м, их залесенность снижается - преобладают березовые и сосновые леса.

Питание реки происходит в основном за счет весеннего таяния снегов и, в меньшей степени, летних дождей и грунтовых вод [8]. Основное русло реки 
располагается на дерново-подзолистых и легко суглинистых валунах и на пылевато-суглинистых покровных породах [7]. Река считается одной из мало загрязненных, хотя некоторые участки испытывают локальное загрязнение, но в целом река умеренно загрязненная, относится к $\beta$-мезосапробным водоемам, что подтверждается данными гидрохимического [1] и микробиологического [9] анализов. Река используется как место рекреации и любительского лова рыбы, особенно в её живописном нижнем течении. Имеет питьевое, а в низовье и рыбохозяйственное значение [8].

В работе представлены данные полевых исследований берегов и акватории реки Улеймы в 2014-2018 годах. За основу оценки экотопической расчлененности водотока взята классификация природно-аквальных комплексов Е.Ю. Колбовского [2]. Сбор гербарного материала и описание сообществ осуществляли маршрутным методом с берега и воды на лодке. Описание водной и околоводной растительности проводилось на серии площадок, закладываемых во всех фитоценозах участка с охватом от 10 (в обширных и однородных сообществах) до 100 \% (в сообществах с высокой мозаичностью и малой площадью) их площади. В условиях мелкоконтурности речных фитоценозов использовали площади в $4 \mathrm{M}^{2}$. В геоботанический бланк описываемого фитоценоза заносилась общая информация по водному объекту, отмечалось общее состояние фитоценоза, аспект, флористический состав, распределение видов по ярусам. Участие видов в конкретных типах растительности оценивали глазомерно по 7балльной шкале оценки покрытия-обилия Браун-Бланке и 4-балльной шкале встречаемости. Под макрофитами водотока понимались крупные водоросли и высшие травянистые и древесные растения, способные нормально развиваться в условиях воды или водопокрытого грунта [3-5]. Название ассоциаций фитоценозов давалось на доминантно-детерминантной основе. Для установления закономерностей размещения фитоценозов в пространстве в зависимости от условий местообитания был использован метод экологического профилирования. Было заложено 24 профиля: в нижнем течении реки -7, среднем -8, верхнем -7. Графическое построение профильного хода выполнялось в программе CorelDRAW. В качестве выделов на линии приводятся ассоциации, нанесенные по определенному символу доминанта и детерминанта.

За период 5-летних исследований на реке было зафиксировано 143 вида сосудистых растений, относящихся к 91 роду, 42 семействам, 4 классам и 3 отделами. Основной объем флоры составляют цветковые растения, среди которых 92 вида двудольных и 48 видов однодольных растений; споровые сосудистые растения представлены 2 видами хвоща - Equisetum fluviatile, E. pratense и 1 видом папоротника - Athyrium filix-femina. Десятку ведущих по числу видов семейств составляют Роасеае (16), Asteraceae (11), Сурeraceae (10), Rosaceae (9), Ranunculaceae (8), Potamogetonaceae (7), Polygonaceae (7), Juncaceae (6), Lamiaceae (6), Salicaceae (6). Остальные 32 семейства являются маловидовыми (1-3 вида). 
Зарастание русла и берегов водотока связано с водными макрофитами, среди которых 20 видов являются гидрофитами, 9 видов - гелофитами и 8 видов - гигрогелофитами. Видовой состав гидрофильного «ядра» флоры за годы исследований не претерпел значительных изменений. Вместе с тем, нестабильность уровня воды в нижнем течении реки (зоне подпора) сказалась на обилии и встречаемости ряда видов. Так, в маловодный 2015 год наибольшим обилием и широким распространением на данном участке реки отличились Agrostis stolonifera, Alisma plantago-aquatica, Batrachium circinatum, Carex acuta, Nuphar lutea, Phragmites australis, Sagittaria sagittifolia, Scirpus lacustris, Sparganium erectum; в полноводные 2014, 20162018 годы - Glyceria maxima, Nymphaea candida, Persicaria amphibia, Potamogeton lucens, P. perfoliatus, Rorippa amphibia. Нестабильной по числу видов в составе флоры является группа береговых (околоводных) растений, активность которых возрастает на береговых отмелях и обнажениях в период спада воды. Вместе с тем среди этих растений ежегодной устойчиво высокой активностью характеризуется гигрофильный вид Phalaroides arundinaceae, формирующий сплошные заросли протяженностью до полусотни метров и более на песчаных отмелях и косах (побочнях) по всему водотоку.

Растительность реки сложена 74 ассоциациями, которые относятся к 25 формациям, 3 классам водной растительности.

В целом, растительный покров на реке развит неравномерно, как и вклад описанных сообществ в зарастание водоема оказался различным, что связано с геоморфологией реки и набором природно-аквальных комплексов в разных частях речного русла.

В верховьях, где повышенное течение, русло реки зарастает гидрофитами в среднем на $20 \%$; группировки водных растений развиваются на середине - в стрежневой части. На этом участке местами имеются прирусловые песчаные отмели, почти лишенные водной растительности. В среднем течении сообщества развиты лучше (зарастание доходит до 40 \%), встречаются чаще на излучинах и гравийно-галечных перекатах реки. Основная роль в зарастании русла принадлежит сообществам Potamogeton perfoliatus, P. pectinatus, Butomus umbellatus, которые встречаются на всём протяжении данного отрезка; тянутся длинными лентами по дну русла в стрежени, образуя «подводные луга». Из других видов гидрофитов значительные скопления местами образуют Nuphar lutea, Potamogeton natans. у Nuphar lutea преобладает подводная форма. Проективное покрытие фитоценозов настоящих водных растений достаточно высокое: полностью погруженных составляет в среднем 60-70 \%, до $100 \%$ (Batrachium circinatum), нимфеид - в среднем 50-60\%, местами до $80 \%$ (Potamogeton natans). Сообщества в большинстве своем монодоминантные (одновидовые). К редким сообществам данного участка водотока относятся группировки, $B$. Kauffmanii, Elodea canadensis.

Сообщества прибрежно-водных растений в верховье реки также не получают развития из-за высокого течения, в среднем течении перед зоной 
подпора они тянутся полосами шириной 1-4 (10) м вдоль береговой линии, прерываясь на участках с крутыми берегами. Доминирование в этой части водотока получают Equisetum fluviatile, Carex acuta, Phragmites australis, образующие преимущественно чистые заросли. Исключительно подводной формой в виде вегетативных особей с длинными лентовидными листьями представлен Butomus umbellatus, который подобно рдестам (Potamogeton perfoliatus, $P$. pectinatus) на плёсах и гравийно-галечных перекатах реки образует «подводные луга» по всей ширине русла. Куртинными скоплениями среди зарослей доминантов встраиваются сообщества Sagittaria sagittifolia, Scirpus lacustris, Sparganium erectum.

Характер размещения сообществ водных и прибрежно-водных растений в экотопах с повышенным течением в русле реки представлен на серии профилей (см. Рис. 1-3).

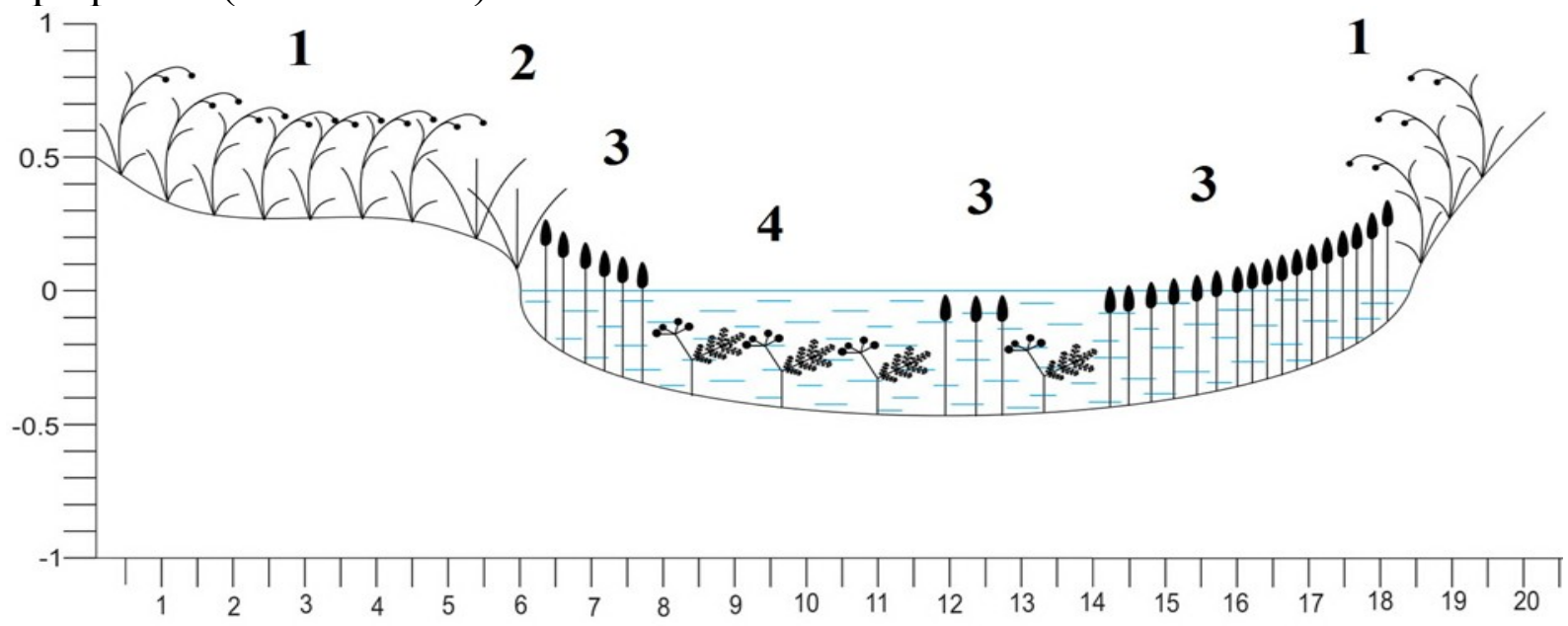

Рис.1. Распределение сообществ макрофитов по ширине поймы.

Условные обозначения: 1 - Phalaroidetum arundinaceae; 2 - Carecetum acuti; 3 - Scirpetum lacustris; 4 - Oenanthetum aquaticae.

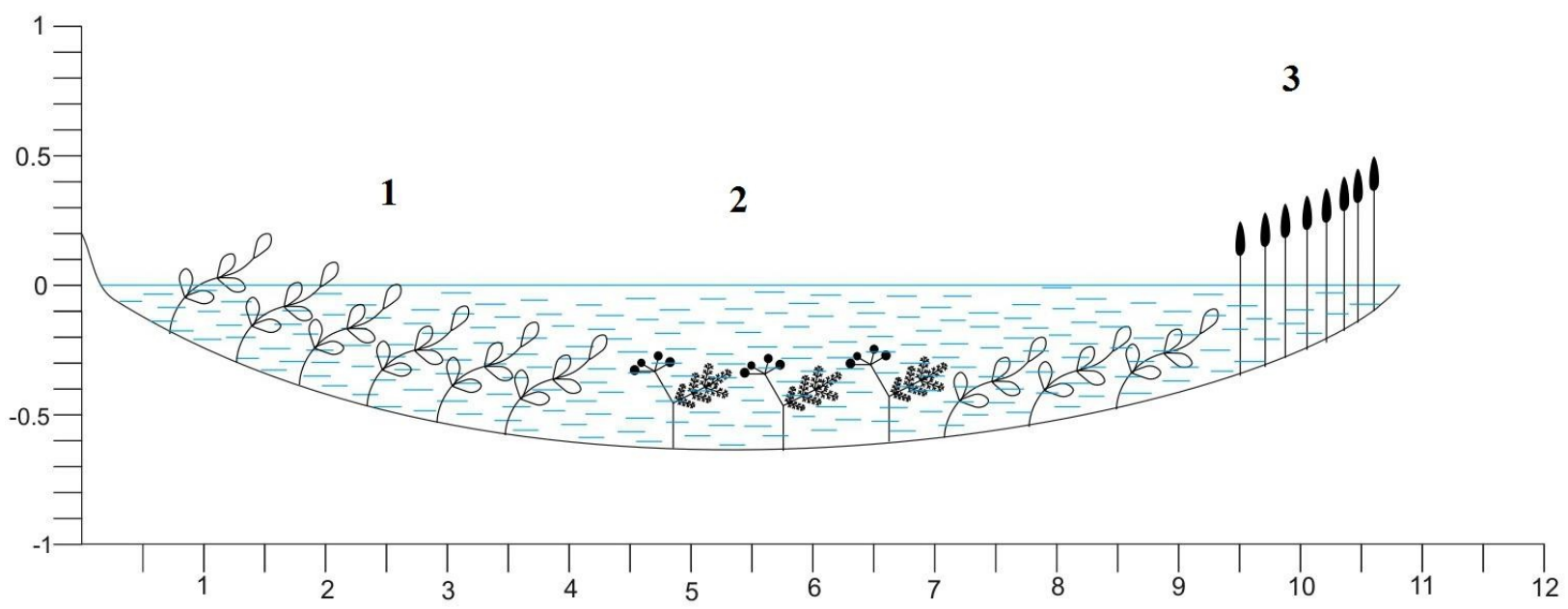

Рис.2. Распределение сообществ макрофитов на гравийно-галечном перекате.

Условные обозначения: 1 - Potametum perfoliati; 2 - Oenanthetum aquaticae; 3 - Scirpetum lacustris. 


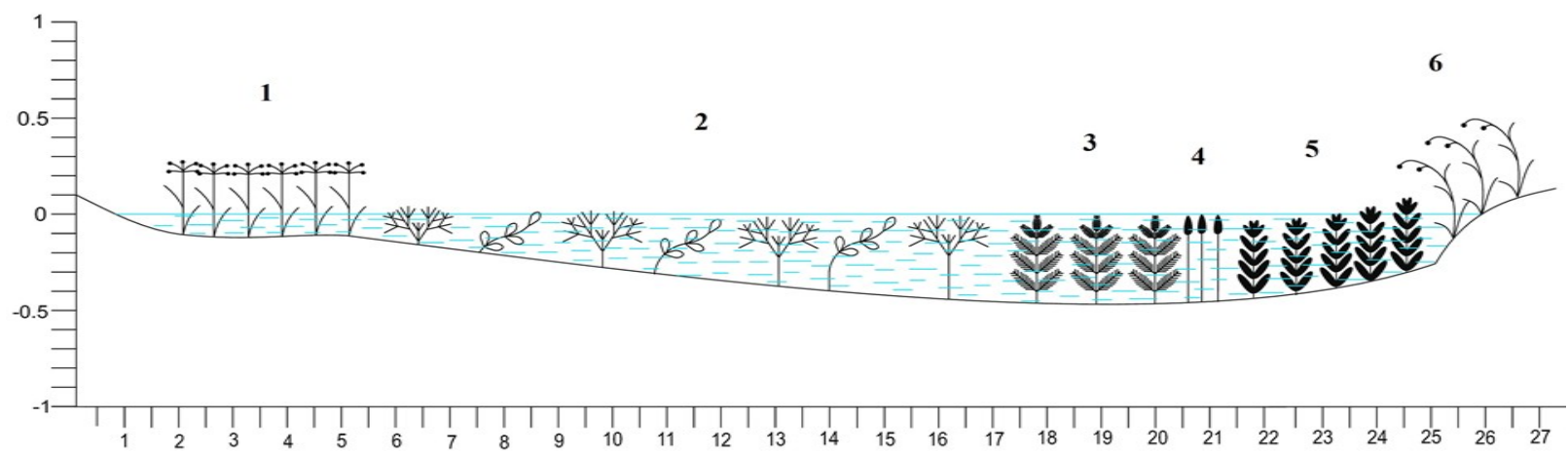

Рис.3. Распределение сообществ макрофитов в русле.

Условные обозначения: 1 - Scirpetum radicans; 2 - Potameto perfoliatipectinati; 3 - Myriophyllum spicati, 4 - Scirpetum lacustris; 5 - Elodeetum canadensis.

В среднем течении русла местами возникают округлые или вытянутые по фарватеру русла песчаные образования - побочни («островки»), зарастающие Equisetum fluviatile, Phalaroides arundinaceae, Scirpus lacustris, гигрофильными видами ивы, и делящие русло на несколько рукавов. Участки русла между побочнями образуют перекаты, в которых длинными лентами стелется рдест пронзеннолистный, сусак зонтичный и омежник водный. Плёсы в русле, располагаясь против выпуклых краёв побочней, в основном свободны от растительности.

К редкому типу экотопов, сформировавшемуся в среднем течении реки, относится отшнуровавшаяся маленькая старица (10х5 м), всю поверхность акватории которой занимает Potamogeton natans (до 40\% покрытия) (Рис. 4).

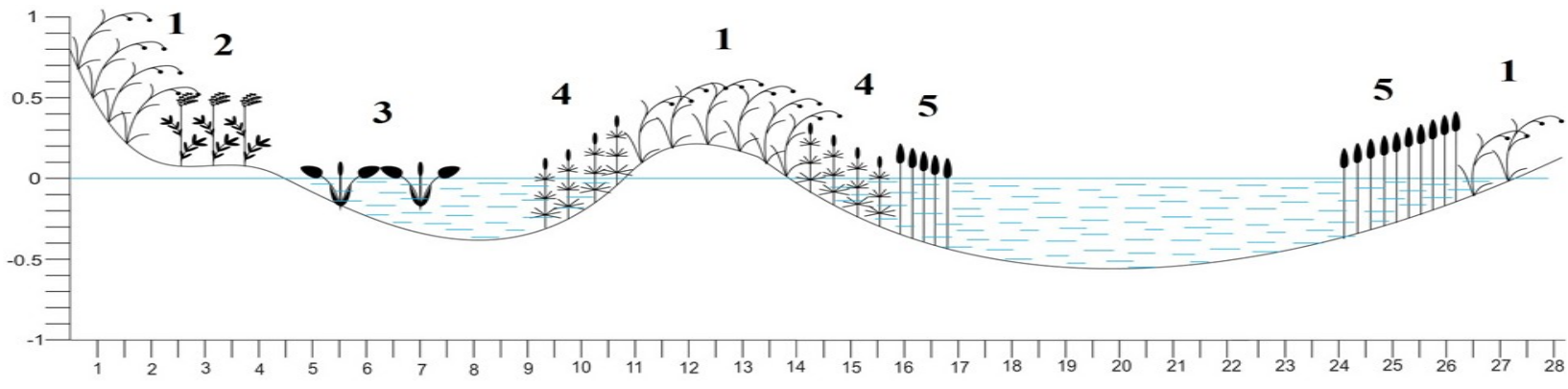

Рис.4. Распределение сообществ макрофитов в пойме. Условные обозначения: 1 - Phalaroidetum arundinaceae; 2 - Filipendulum ulmarae; 3 Potametum natansi; 4 - Equisetum fluviatili; 5 - Scirpetum lacustris.

Приплотинные участки - еще один тип экотопов в верховье реки, возникли от зарегулирования русла действующей (перед селом Улейма) и двумя разрушенными плотинами. Зарастание приплотинных участков происходит по типу «зонного» (поясного) распределения сообществ макрофитов от береговой линии с постепенным продвижением к центру 
водного объекта (Рис.6.), где береговую бровку заселяет Carex acuta (ПП=60\%) с единичным участием Epilobium hirsutum, E. palustre, Lythrum salicaria, Filipendula ulmaria, Rumex aquaticus. Её сообщества на мелководье замещает Equisetum fluviatile с Persicaria amphibia. С нарастанием глубин получают развитие сообщества Nymphaea candida (ПП=30\%) с Potamogeton lucens (ПП=10\%). Фарватер лишён растительности.

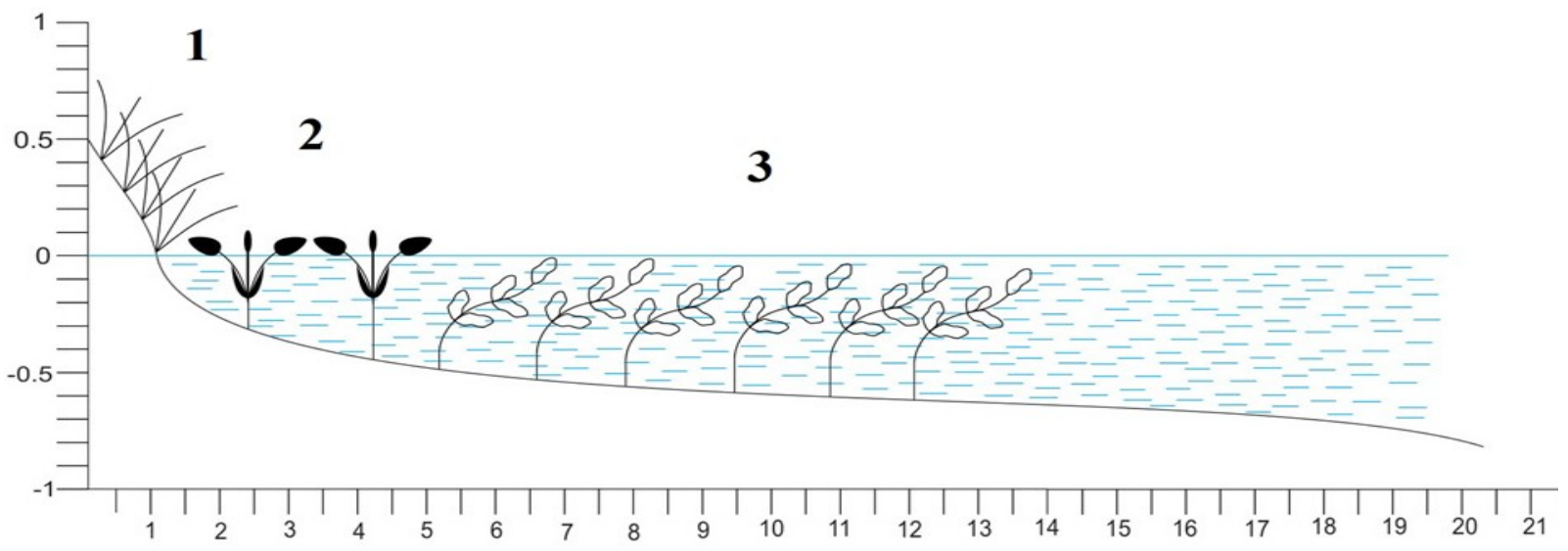

Рис.5. Распределение сообществ макрофитов в приплотинном участке.

Условные обозначения: 1 - Carecetum acuti; 2 - Potametum natansi; 3 Potametum lucensi.

Сходным образом происходит распределение сообществ в границах приплотинного участка у села Улейма (рис.6).

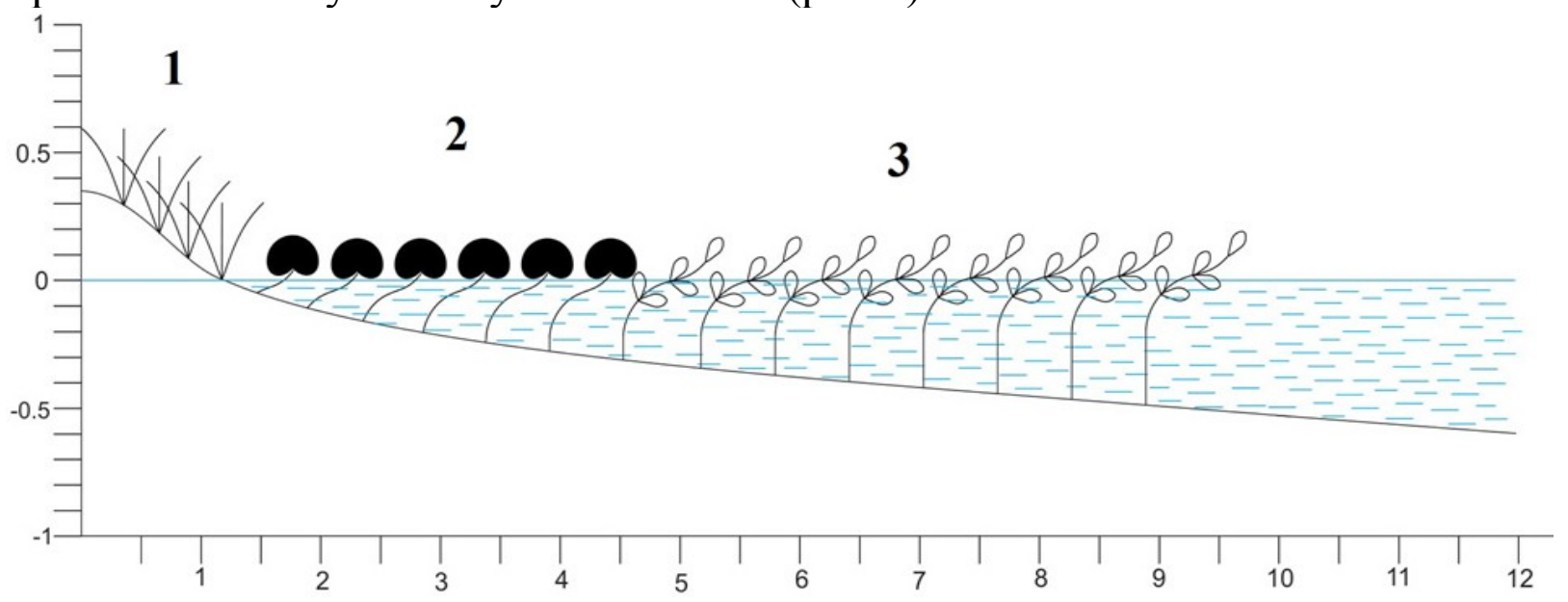

Рис.6. Распределение сообществ макрофитов в водохранилище.

Условные обозначения: 1 - Carecetum acuti; 2 - Nymphaetum candidi subpurum; 3 - Potametum perfoliati.

В созданном действующей плотиной перед с. Улейма искусственном водоёме растительность характеризуется таким же зонным распределением, с той лишь разницей, что значительный вклад в зарастание мелководий вносит сообщества гелофитов, представленная зарослями Phragmites australis, Equisetum fluviatile (Рис.8). С нарастанием глубин они замещается 
гидрофитами Potamogeton perfoliatus $(\Pi \Pi=50 \%)$ с участием Nymphaea candida, Lemna minor.

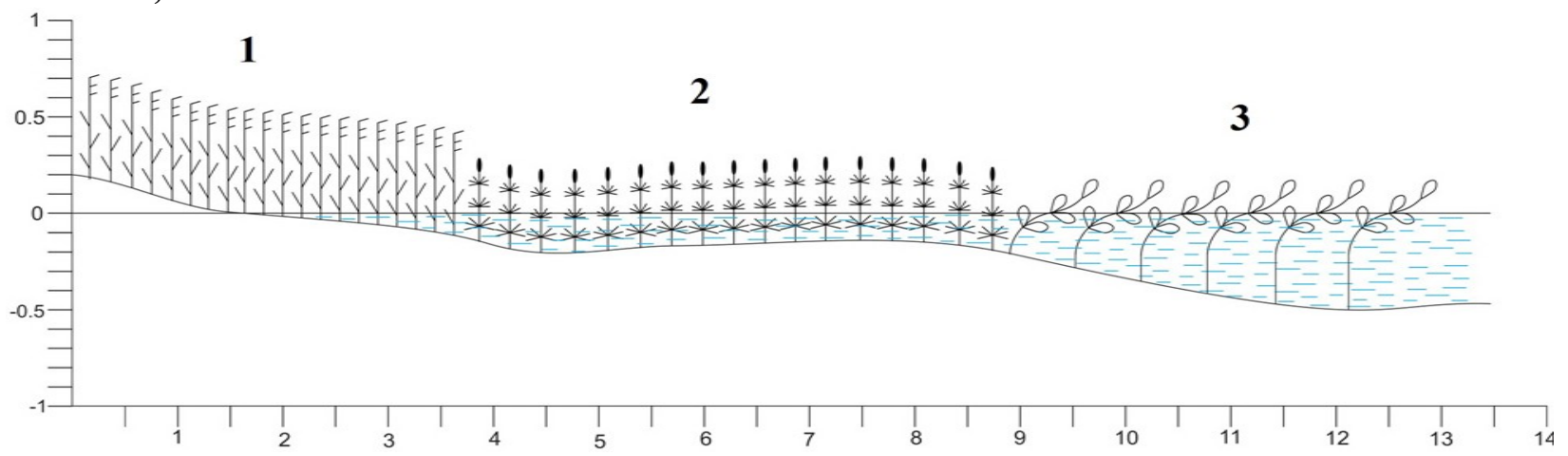

Рис.7. Распределение сообществ макрофитов в водохранилище.

Условные обозначения: 1 - Phragmitetum australis; 2 - Equisetum fluviatili; 3 - Potametum perfoliati.

В нижнем течении река становится широкой (в среднем 100 м, до 150 м в устьевом створе), извилистость реки слабая, перекаты отсутствуют, течение замедленное, прозрачность низкая (до 1,5 м), глубина постепенно нарастает от 2 до 5 м в месте впадения в р. Юхоть. Дно русла песчаное, в устье грунты наносные, заиленные; мощность наилка доходит до 10 см под сообществами гидрофитов. В приустьевой часто наблюдается спад и подъём воды, из-за чего может возникнуть обратное течение.

Общая площадь зарастания русла в нижнем течении в целом не превышает $20 \%$. Она не является постоянной в количественном и качественном отношении и зависит от полноводности реки и перепадов уровня воды, вызванных влиянием Рыбинского водохранилища и годовыми и сезонными колебаниями стока.

Так, например, в маловодный 2015 год побочень близ устья выглядело следующим образом: Carecetum acuti $\rightarrow$ Agrosteto stoloniferi-Alismatetum plantago-aquaticae $\rightarrow$ Glyceretum maximae $\rightarrow$ Phalaroidetum arundinaceae.

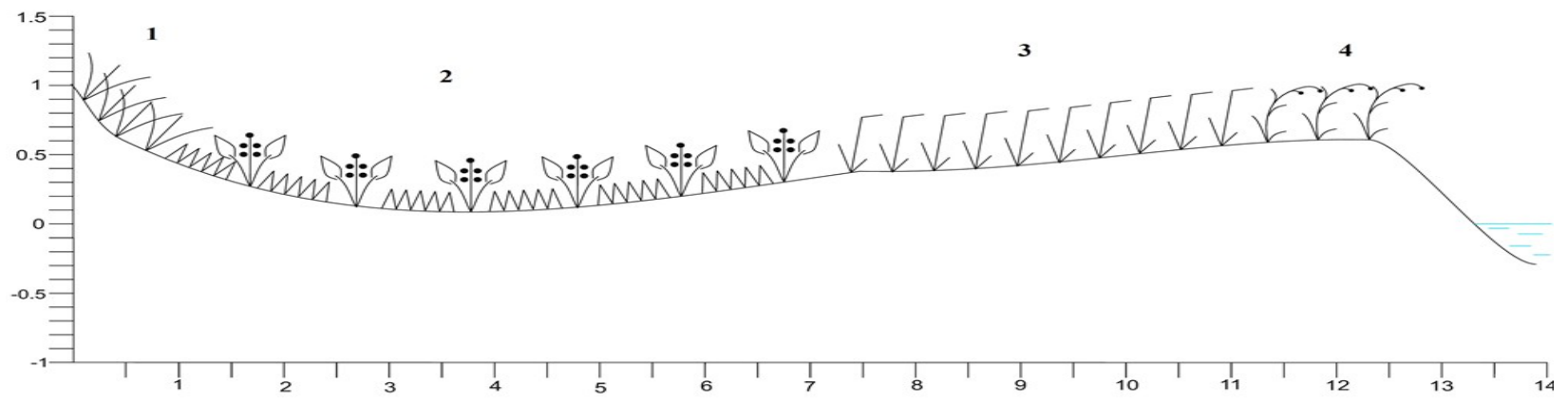

Рис.8. Распределение сообществ макрофитов в пойме.

Условные обозначения: 1 - Carecetum acuti; 2 - Agrosteto stoloniferiAlismatetum plantago-aquaticae; 3 - Glyceretum maximae; 4 - Phalaroidetum arundinaceae.

В полноводный 2017 год в результате затопления того же экотопа поменялся облик растительности в его границах: оводненность участка 
позволила реализоваться новым видам макрофитов - Equisetum fluviatile, Potamogeton lucens, Rorippa amphibia, сформировавших свои сообщества при наличии подходящих глубин (Рис. 9).

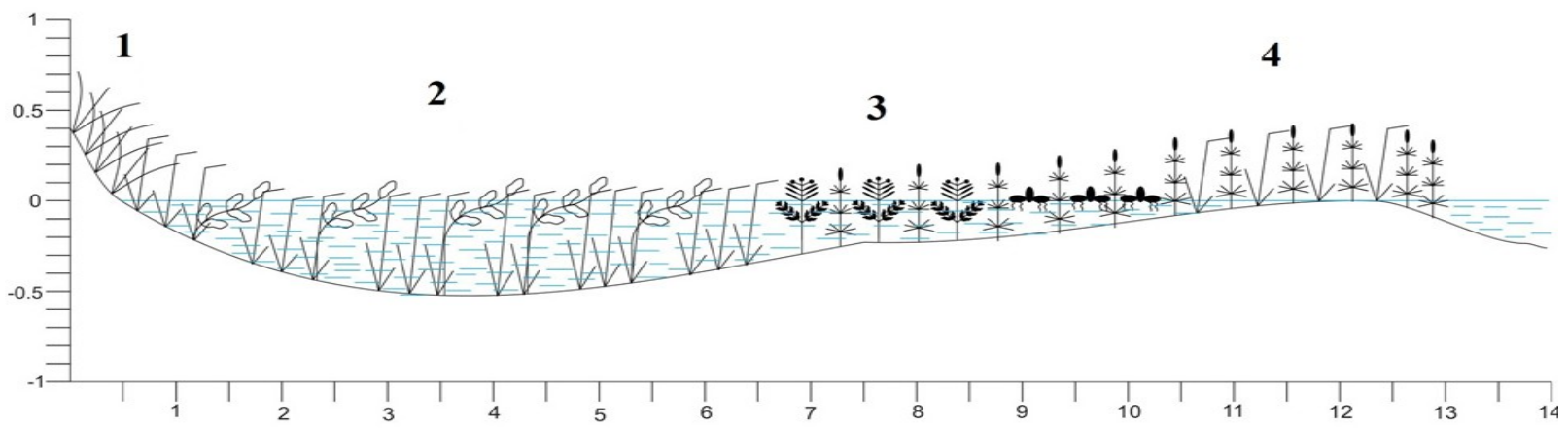

Рис.9. Распределение сообществ макрофитов в пойме.

Условные обозначения: 1- Carecetum acuti; 2 - Glycereto maximaePotametum lucensi; 3 - Rorippo amphibiae-Equisetum fluviatili; 4 - Equiseto fluviatili-Glyceretum maximae.

В целом интенсивность зарастания снижается от верховья подпора к устью. Центральная часть русла в силу больших глубин и обрывистые берега лишены какой-либо растительности. Сообщества встречаются в местах русла с пологими берегами, на песчаных косах, в заливах. Большинство прибрежно-водных растений заходит в воду до глубин 0,5 м, и только Scirpus lacustris продвигается вглубь акватории на глубину до 1,5 м. Сообщества погруженных гидрофитов и нимфеид развиваются на глубинах от 0,5 до 2 м.

В нижнем течении реки получают распространение еще один тип экотопов - заливы. Одни из них узкие, затененные (облесенные до самой воды), с высокими берегами, в которые впадают лесные ручью, другие осветленные, лагунообразные, с низкими пологими берегами, отделяемые от русла песчаной косой.

Наибольшим видовым и экосистемным разнообразием характеризуются осветленные заливы, в которых количественно преобладают сообщества погруженных гидрофитов Potamogeton lucens, P. perfoliatus, с проективным покрытием до 70\%, нимфеид Nymphaeae candida и Nuphar lutea (плавающие формы) в совместном произрастании и отдельно с покрытием от 40 до 60\%, Persicaria amphibia - с покрытием от 50 до 70\% (Рис.10). В летнюю межень при спаде воды на мелководье (до 0,3 м) получают развитие сообщества Batrahium circinatum, сильно обрастающие нитчатыми водорослями (роды Spirogira, Mougeotia) со «вспучиванием» последних, из прибрежно-водных растений - Alisma plantago-aquatica, Sagittaria sagittifolia, Sparganium emersum. Значительным бывает вклад на мелководье заливов водноболотных растений Oenanthe aquatica, Sium latifolium, Rorippa amphibia, создающих аспект при массовом развитии. Заходящие в виду береговые (околоводные) растения в заливах не получают значительного развития, формируются в приурезовой части небольшими, часто разорванными, вместе 
с тем плотными (проективное покрытие до 90\%) куртинными скоплениями, характеризующиеся наибольшим видовым богатством сообществ.

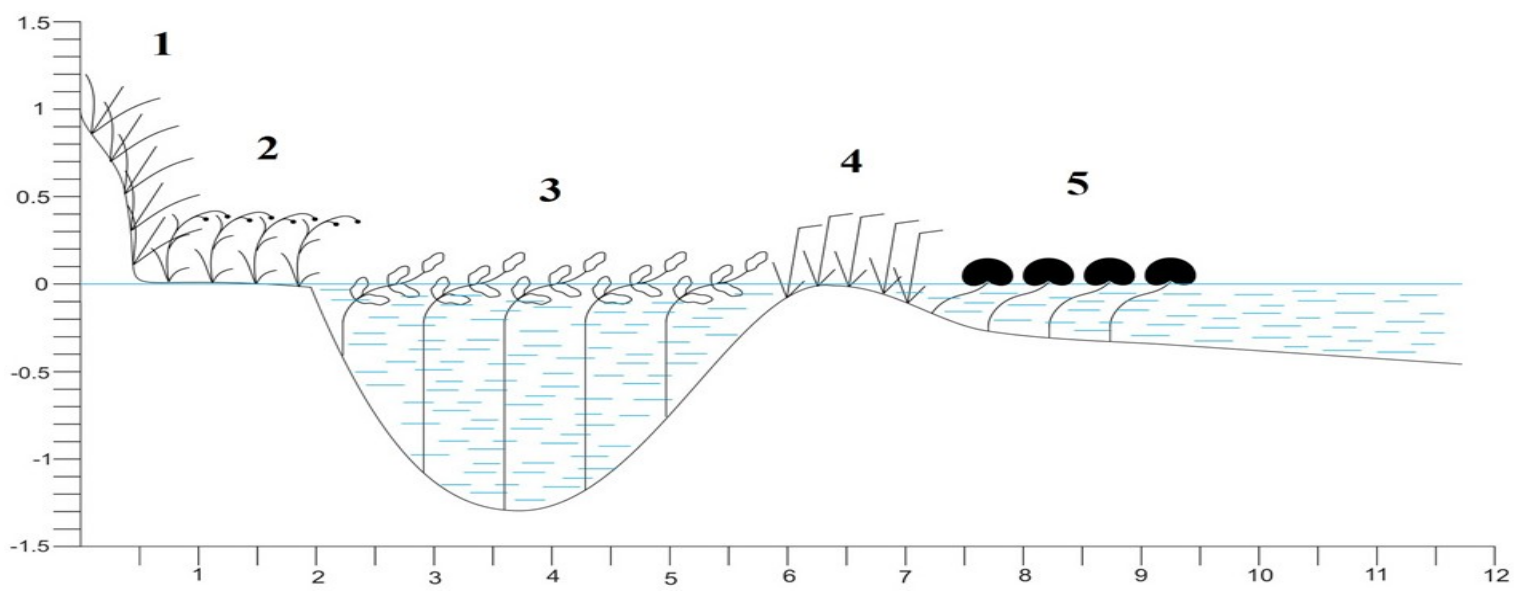

Рис.10. Распределение сообществ макрофитов в заливе.

Условные обозначения: 1- Carecetum acuti; 2 - Phalaroidetum arundinaceae; 3 - Potametum lucensi; 4 - Glyceretum maximae; 5 -Nupharetum luteae.

Затененные заливы зарастают значительно слабее; в видовом и ценотическом отношении они беднее, чем осветленные. В них узкими полосами просматриваются группировки Carex acuta, Alisma plantagoaquatica, Sagittaria sagittifolia (подводная и надводная формы), в воде - плохо оформленные куртины Potamogeton perfoliatus и Nuphar lutea.

Иная картина зарастания создаётся на мелководье прямых участков русла. Основную площадь мелководной зоны в русле занимают заросли Phalaroides arundinaceae или Glyceria maxima, гидрофиты же представлены небольшими куртинными скоплениями (Рис. 11).

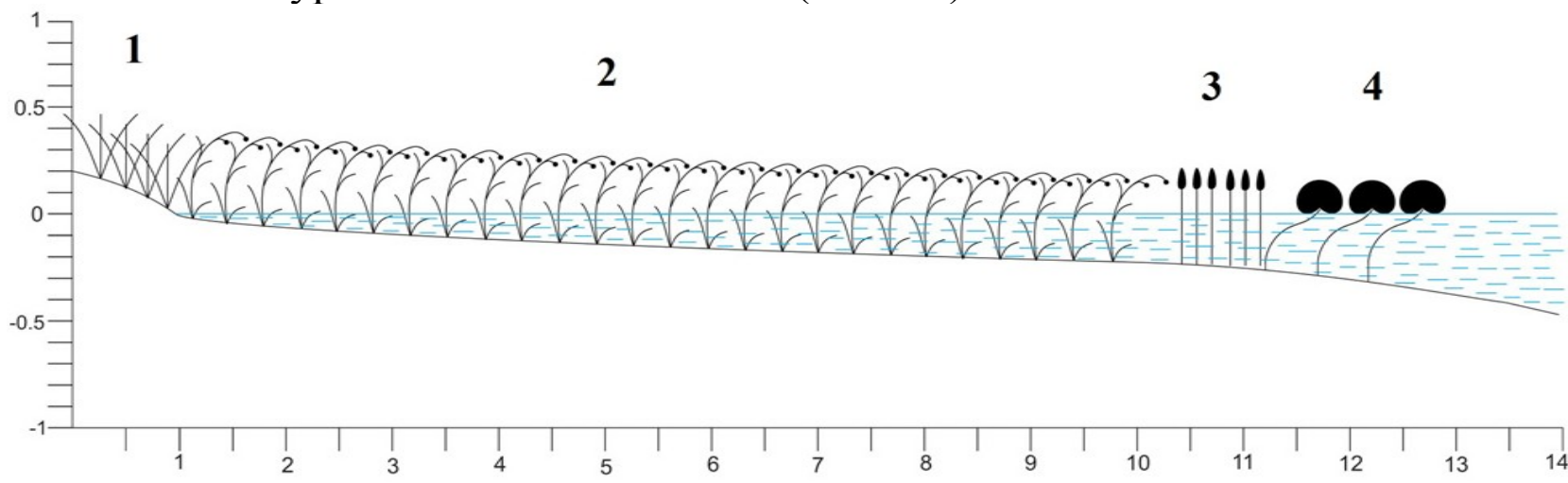

Рис.11. Распределение сообществ макрофитов на пойме.

Условные обозначения: 1 - Carecetum acuti; 2- Phalaroidetum arundinaceae; 3 - Scirpetum lacustris; 4 - Nymphaetum candidi subpurum.

Сообщества свободно плавающих гидрофитов (виды семейства Lemnaceae, Hydrocharis morsus-ranae - индикаторы на биогенное эвтрофирование водоемов), в реке не получают развития. Встречаются среди 
гигрофильного кустарника, в прибрежных зарослях и сообществах нимфеид в виде отдельных особей.

\section{Заключение}

Экотопическое разнообразие реки оценивается 11 местообитаниями, относящихся к 6 типам природо-аквальных комплексов, типичных для водотоков Ярославского Поволжья, как и традиционным для бассейна Верхней Волги набором видов макрофитов и образованных ими ценозов.

Число доминантов сообществ невелико по сравнению с числом видов, определяющих объем флоры сосудистых растений водотока: из околоводных растений - Carex acuta, Phalaroides arundinaceae, Rorippa amphibia; прибрежно-водных - Equisetum fluviatile, Glyceria maxima, Sagittaria sagittifolia, Scirpus lacustris, гидрофитов - Nymphaea candida, Nuphar lutea, Persicaria amphibia, Potamogeton lucens, P. perfoliatus. Все группировки водных и прибрежно-водных растений в основном монодоминантные, просты по структуре (одно-двухярусные) и бедны по флористическому составу.

Наибольшего развитие высшая водная растительность достигает в осветленных заливах и приплотинных участках со слабым гидрологическим режимом, тогда как в русле и затененных заливах степень зарастания снижается. Во всех экотопах наблюдается преобладание сообществ гидрофитов над ценозами прибрежно-водных растений за исключением участков с повышенным течением. Доля сообществ околоводных и прибрежно-водных растений возрастает с увеличением площади мелководной зоны в русле.

На участках с высоким и среднем течением выдерживается ленточное распределение ценозов и разрастающихся клонов макрофитов, которые образуют «подводные луга» в русле водотока, в экотопах с отсутствием течения - «зонное» распределение ценозов вдоль береговой линии с постепенным продвижением к центру водотока.

Большее влияние на пространственное распределение сообществ макрофитов оказывает изрезанность береговой линии, скорость течения и глубина руслового ложа.

\section{Список литературы}

1. Воропаева, О.Г. Гидрологический и альгологический режим р. Улейма / О.Г. Воропаева, А.В. Рязанова, Н.А. Аненкова, И.А. Суханова. Рук. Деп. в ВИНИТИ. № 2302-83.05.83.

2. Колбовский, Е.Ю. История и экология ландшафтов Ярославского Поволжья: Монография/ Е.Ю. Колбовский. - Ярославль: ЯГПИ им. К.Д. Ушинского, 1993. - 113c.

3. Папченков, В.Г. Растительность водоемов и водотоков Среднего Поволжья / В.Г. Папченков. - Ярославль: ЦМП МУБиНТ, 2001. - 214 с. 
4. Папченков, В.Г. О классификации растений водоемов и водотоков / В.Г. Папченков // Гидроботаника: методология, методы: Материалы Школы по гидроботанике / В.Г. Папченков. - Рыбинск: ОАО «Рыбинский Дом печати», 2003. - С. 23-26.

5. Папченков, В.Г. Доминантно-детерминантный подход классификации водной растительности / В.Г. Папченков // Там же. - С. 126-131.

6. Рохмистров, В.Л. Некоторые морфологические характеристики рек Ярославского Поволжья / В.Л. Рохмистров // Ученые записки ЯГПИ. Вып. 4. География и геология. - Ярославль, 1969. - 102 с.

7. Рязанова, А.В. Гидрохимический режим реки Улеймы / А.В. Рязанова, В. Соловьева // Вопросы общей экологии и исследование элементов экосистем Нечерноземной зоны РСФСР. - Иваново, 1981. - С. 135-148.

8. Семерной, В.П. Биономическая характеристика реки Улеймы и задачи ее охраны / В.П. Семерной // Вопросы общей экологии и исследования элементов экосистем Нечерноземной зоны РСФСР. - Иваново, 1981. - С. 122-134.

9. Филина, Н.Ю. Микробное разнообразие ила реки Улеймы как показатель экологического состояния водоема / Н.Ю. Филина, Н.В. Верховцева, Г.А. Осипов // Биотехноэкологические проблемы бассейна Верхней Волги. - Ярославль: Изд-во ЯрГУ, 1998. - С. 61-64.

10. Чемерис, Е.В. Растительный покров истоковых ветландов Верхнего Поволжья / Е.В. Чемерис: автореф. дис. ... канд. биол. наук. - СПб., 2004. $18 \mathrm{c}$. 